\title{
COMBINED EFFECT OF SALINE AND MAGNETIZED WATER AND BIOFERTILIZER ON NODULATION AND GROWTH OF COMMON BEAN PLANTS GROWN IN CLAY AND SANDY SOILS
}

\author{
Manal F.A. Tantawy, M.N. Fiyad, Fatma S. El-Shafei and S.A.S. Marei \\ (1) Soils, Water and Environment Res. Inst.- Agric. Res. Center - Giza \\ (2) Soil Science Dept., Fac. of Agric Menoufia University
}

Received: Oct. 16, 2019

Accepted: Nov. 4, 2019

\begin{abstract}
During winter season of 2015 a pots experiment was carried out at private farm on two soils of Egypt (clay and sandy) varied in their physo and chemical properties to study the individual and combined effects of salinity level of irrigation water either of un-or magnetized irrigation water and biofertilization on nodulation efficiency and growth of common bean plants (Phaseolus vulgaris L Nebrasca c.v). The used salinity levels were 300, 700 and $1900 \mathrm{mg} / \mathrm{l}$. The layout of the experiment was split-split block design in three replicates of each soil.

The obtained data show a significant decrease on nodules number formed on the roots of common bean plants. On the other hand, application of magnetic technique and biofertilizer resulted in a significant increases of nodules number. These findings may be cleared from the calculated relative change values "RC" of the studied three factors on nodulation number. With the same treatment nodules number formed on the roots of common bean plants grown on clay soil was higher than that formed on the plants grown in sandy soil. Similar effect for the studied three factors was found on both fresh and dry weights (g/pot) of common bean plants (shoots) at growth period of 45 day: These results concluded that, applying magnetic technique and biofertilizer application decreased the hazard effect of water salinity and increased nodulation efficiency and plant growth.
\end{abstract}

Key words: Common bean, Nodulation, Saline water, Magnetic technique and Biofertilizer.

\section{INTRODUCTION}

Magnetic energy is one type of the energy which exists in the universe. The earth surrounded by magnetic variable which has an effect on all things with leveled markers and this energy is very important for living on the land to the living parts. It was found that, the magnetic treatments alter the water relations in seeds, in the ionic concentration and osmotic pressure and water uptake rate by seeds and this affects the germination rate of seeds (Garcia-Reina and Pascual, 2001).

Magnetically treated water (MTW) is water which has been passed through a magnetic field prior to use. There are a lot of benefits to using such treated water, although there is still considerable debate as to its efficiency. Deng and Pang (2007) investigated the mechanism of magnetization of water and proposed a theory based on the molecular structure of water. In the model proposed by Pang and Deng (2008), the interaction of the externally applied magnetic field with the electric current arising from the protons (or hydrogen ions) enhance conductivity along the closed hydrogen bonded chains of molecules occurring in water.

Approximately $20 \%$ of the world's cultivated land and nearly half of all irrigated land are affected by salinity (Zhu, 2001). Therefore, salinization has 
been a major factor limiting agricultural crop production (Parida and Das, 2005). Hence, the salt tolerance of crops is necessary to sustain the increasing demand in food production in many regions in the world. The future of irrigated agriculture poses the need to develop irrigation strategies using saline and deficit irrigation water to fulfill the food and fiber production gap, in order to ensure long term sustainability in irrigated agriculture. Salinity is one of major environmental factor reducing plant growth and productivity worldwide in arid and semi-arid regions (Munns, 2002). The direct effect of salt on plant growth may be divided into three broad categories (i) a reduction in the osmotic potential of the soil solution that reduces plant available water, (ii) a deterioration in the physical structure of the soil such as water permeability and soil aeration are diminished, and(iii) increase the concentration of cation and ions that have an inhibitory effect on plant metabolism (specific ion toxicity and mineral nutrient deficiencies) (Omami, 2005).

There are two types of supplies for agriculture, specifically fertilizer and pesticide. It can be said that fertilizer is food, and pesticide is medicine for plants in conventional agriculture. On the other hand, biofertilizer and I or biopesticide are referred to each of them respectively in sustainable or environmentally friendly system. Biofertilizers are low cost, renewable sources of plant nutrients which supplement chemical fertilizers. These are nothing but selected strains of beneficial soil microorganisms cultured in the laboratory and packed in a suitable carrier. They can be used either for seed treatment or soil application. Biofertilizers generate plant nutrients like nitrogen and phosphorous through their activities in the soil or rhizosphere and make available to plants in a gradual manner. Biofertilizers are gaining momentum recently due to the increasing emphasis on maintenance of soil health, minimize environmental pollution and cut down on the use of chemicals in agriculture. In rainfall agriculture, these inputs gain added importance in view of their low cost, as most of the farmers are small and marginal and cannot afford to buy expensive chemical fertilizers. Biofertilizers are also ideal input for reducing the cost of cultivation and for practicing organic farming (Muraleedharan et al., 2010).

French beans or common bean (Phaseolus vulgaris L.) is one of the most important vegetable crops as fresh or frozen after cooking and common diet in Egypt. It is considered as a good source of protein, carbohydrates and nutrient elements. Expanding such legume cultivation in newly reclaimed lands is considered as an important way to increase their productivity via improving soil fertility.

Therefore, this study was carried out to study and evaluate the combined effect of salinity levels of irrigation water either of non-magnetized or magnetized on common beans plants (Phaseolus vulgaris L.) Nebrsca cv., fertilized by biofertilizer under clay and sandy soil conditions. Fresh and dry weights of the growing plant in relation with the studied treatments were determined.

\section{MATERIALS AND METHODS Soil Samples}

In this study, two soils of Egypt varied in their physical and chemical properties were used. The first soil was taken from Gezerit El-Hagar Village, El-Shohada, Minufiya Governorate, where this soil represent the fine soil texture (clay). The second soil representing sandy soil was taken from El-Emam El-Hussien Village, El-Bostan area, El-Delengate, Behaira Governorate which representing sand soil . From each location, surface soil 
sample (0-30 $\mathrm{cm}$ depth) was taken separately. The collected sample from each location was air-dried, ground, good mixed and sieved through a $2 \mathrm{~mm}$ sieve. A portion of fine soil samples were used in some chemical and physical determinations, the content of available macro-and micronutrients were determined according to the methods described by Cottenie et al. (1982), Page et al. (1982) and Klute (1986) and the obtained data recorded in Table (1). Another soil was used in the green house experiments.

\section{Irrigation Water}

Three resources of irrigation water were used in this study. These water resources varied in their salinity level. The first resource (IW1) was tap water at salinity level of $300 \mathrm{mg} / \mathrm{L}$. The second resource (IW2) was taken from one well of El-Emam El-Hussien Village, El-Bostan area, El-Delengate, Behaira Governorate which have a salinity level of $700 \mathrm{mg} / \mathrm{L}$. The third resource (IW3) represent ground water at salinity level of $1900 \mathrm{mg}$ $\mathrm{I}^{-1}$ which taken from one well of ElTabarany Village, Wadi El-Natroun, ElBehaira Governorate. The used three irrigation water resources were magnetized by passing a magnetic field and will acquire a magnetic moment 48 72 hours after crossing the magnetic field. However, such time is good enough for magnetized irrigation water to impose magnetic effect on the soil plant-water system. The irrigation water passed throws 1000 Gauss magnetron of 0.5 inch diameter which produced by magnetic technologies (Takatchenko, 1997). Chemical composition of the three irrigation water resources before and after magnetization was carried out according to the methods illustrated by Cottenie et al. (1982). The obtained data were recorded in Table (2).

Table (1): Some physical and chemical properties and the content of available some nutrients of the tow used soils.

\begin{tabular}{|c|c|c|c|c|c|c|c|c|c|c|c|}
\hline \multirow{4}{*}{$\begin{array}{l}\text { Physical } \\
\text { properties }\end{array}$} & \multirow{2}{*}{ Soil } & \multicolumn{6}{|c|}{ Particles size distribution (\%) } & \multirow{2}{*}{\multicolumn{2}{|c|}{$\begin{array}{l}\text { Textural } \\
\text { Grade }\end{array}$}} & \multirow{2}{*}{\multicolumn{2}{|c|}{$\begin{array}{c}\text { WHC } \\
(\%)\end{array}$}} \\
\hline & & \multicolumn{2}{|c|}{ Sand } & Silt & \multicolumn{3}{|c|}{ Clay } & & & & \\
\hline & First & \multicolumn{2}{|c|}{52.15} & 4.09 & \multicolumn{3}{|c|}{43.76} & \multicolumn{2}{|c|}{ Clay } & \multicolumn{2}{|c|}{38.8} \\
\hline & Second & \multicolumn{2}{|c|}{94.4} & 1.0 & \multicolumn{3}{|c|}{4.6} & \multicolumn{2}{|c|}{ Sand } & \multicolumn{2}{|r|}{10} \\
\hline \multirow{5}{*}{$\begin{array}{c}\text { Soil } \\
\text { Salinity }\end{array}$} & \multirow{3}{*}{ Soil } & \multirow{3}{*}{$\begin{array}{c}\text { pH } \\
(1: 2.5) \\
\text { soil: } \\
\text { water } \\
\text { susp. }\end{array}$} & \multirow{3}{*}{$\begin{array}{l}\text { EC } \\
d S \\
m^{-1}\end{array}$} & \multicolumn{8}{|c|}{ Soluble ions (meq/L) } \\
\hline & & & & \multicolumn{4}{|c|}{ Cations } & \multicolumn{4}{|c|}{ Anions } \\
\hline & & & & $\mathrm{Na}^{+}$ & $\mathrm{K}^{+}$ & $\mathrm{Ca}^{2+}$ & $\mathrm{Mg}^{2+}$ & $\mathrm{Cl}^{-}$ & $\mathrm{HCO}_{3}^{-}$ & $\mathrm{CO}^{2-}{ }_{3}$ & $\mathrm{SO}^{2-}$ \\
\hline & Clay & 7.52 & 0.80 & 3.20 & 0.25 & 2.6 & 1.7 & 1.4 & 4.0 & -- & 2.35 \\
\hline & Sandy & 7.37 & 1.2 & 6 & 0.7 & 3.0 & 2.0 & 5.0 & 4.8 & 0 & 1.90 \\
\hline \multirow{3}{*}{$\begin{array}{c}\text { Some } \\
\text { Chemical } \\
\text { properties }\end{array}$} & Soil & $\begin{array}{l}\text { OM } \\
(\%)\end{array}$ & $\begin{array}{l}\text { OC } \\
\text { (\%) }\end{array}$ & \multicolumn{2}{|c|}{$\begin{array}{c}\text { CEC } \\
(\mathrm{Cmol} / \mathrm{kg})\end{array}$} & \multicolumn{2}{|c|}{$\begin{array}{c}\text { Total } \\
N \\
(\mathrm{mg} / \mathrm{Kg})\end{array}$} & \multicolumn{2}{|c|}{$\begin{array}{c}\text { C/N } \\
\text { Ratio }\end{array}$} & \multicolumn{2}{|c|}{$\begin{array}{c}\mathrm{CaCO}_{3} \\
(\%)\end{array}$} \\
\hline & Clay & 1.88 & 1.08 & \multicolumn{2}{|c|}{36.4} & \multicolumn{2}{|c|}{0.057} & \multicolumn{2}{|c|}{19.12} & \multicolumn{2}{|c|}{1.19} \\
\hline & Sandy & 0.60 & 0.34 & \multicolumn{2}{|c|}{11.5} & & 22 & \multicolumn{2}{|c|}{17.0} & \multicolumn{2}{|c|}{1.218} \\
\hline \multirow{4}{*}{$\begin{array}{c}\text { Available } \\
\text { nutrients } \\
\text { (mg/kg) }\end{array}$} & Soil & Macı & nutrie & $\operatorname{ts}(\mathrm{mg}$ & & & Mic & cronut & ients $(m$ & $\mathrm{g} / \mathrm{kg})$ & \\
\hline & SoII & $\mathbf{N}$ & $\mathbf{P}$ & & & $\mathrm{Fe}$ & & $\mathrm{Mn}$ & $\mathrm{Zn}$ & & $\mathrm{Su}$ \\
\hline & Clay & 31.5 & 8.94 & & & 23. & & 12.0 & 1.06 & & .74 \\
\hline & Sandy & 15.2 & 3.22 & & & 4.0 & & 1.22 & 5.35 & & 87 \\
\hline
\end{tabular}


Manal F.A. Tantawy, et al.,

Table (2): Some chemical properties of the irrigation water sources before and after magnetizing.

\begin{tabular}{|c|c|c|c|c|c|c|c|}
\hline \multirow{3}{*}{ Properties } & \multirow{3}{*}{ Units } & \multicolumn{6}{|c|}{ Irrigation water } \\
\hline & & \multicolumn{3}{|c|}{ Non-magnetized water } & \multicolumn{3}{|c|}{ Magnetized water } \\
\hline & & IW1 & IW2 & IW3 & IW1 & IW2 & IW3 \\
\hline $\mathrm{pH}$ & & 7.25 & 8.10 & 8.40 & 7.14 & 7.97 & 8.33 \\
\hline EC & $\mathrm{dSm}^{-1}$ & 0.47 & 1.09 & 2.9 & 0.46 & 1.08 & 2.94 \\
\hline Soluble cations & meqL $^{-1}$ & & & & & & \\
\hline $\mathrm{Na}^{+}$ & & 2.03 & 3.75 & 22.09 & 1.95 & 3.65 & 20.01 \\
\hline $\mathrm{K}^{+}$ & & 0.22 & 0.56 & 0.37 & 0.22 & 0.56 & 0.37 \\
\hline $\mathrm{Ca}^{2+}$ & & 1.95 & 3.50 & 4.85 & 1.95 & 3.50 & 4.85 \\
\hline $\mathrm{Mg}^{2+}$ & & 1.05 & 2.50 & 2.40 & 1.05 & 2.50 & 2.40 \\
\hline Soluble anions & meqL $^{-1}$ & & & & & & \\
\hline $\mathrm{Cl}^{-}$ & & 0.70 & 3.50 & 12.1 & 0.65 & 3.50 & 10.2 \\
\hline $\mathrm{HCO}_{3}^{-}$ & & 1.40 & 3.85 & 6.48 & 1.35 & 3.85 & 6.02 \\
\hline $\mathrm{CO}_{3}{ }^{2-}$ & & ND & ND & ND & ND & ND & ND \\
\hline $\mathrm{SO}_{4}^{2-}$ & & 3.12 & 2.96 & 11.13 & 3.12 & 2.96 & 11.13 \\
\hline SAR & & 1.66 & 2.17 & 11.60 & 1.59 & 2.11 & 10.51 \\
\hline
\end{tabular}

\section{Biofertilization}

The used biofertilizer (Rhizobim phaseolease ) in this study was added in two doses, the first dose was applied to the seeds in a powder form mixed with sucrose solution and Arabic gum, while powder form mixed with sucrose solution and Arabic gum, while the second dose was added to the soil as a liquid together irrigation water after 20 day from planting at rate of $800 \mathrm{~g} / \mathrm{fed}$. Rhizobim phaseolease was brought from Agriculture Microbiology Research Department, Soils, Water and Environment Res. Inst., Agric. Res. Center, Giza, Egypt.

seeds

Common beans are very sensitive to salinity, whether in soil or irrigation water. Also, french beans are one of the most important crops of the legume family and are characterized by good growth and are grown for the consumption of green pods or green and dry seeds, whether for the local market or for export. In this research work, French beans seeds (Phaseolus vulgaris L.), Nebrsca cv. was brought from Horticulture Res. Inst., Agric. Res. Center, Giza, Egypt.

\section{Green House Experiment}

This experiment was carried out in a private farm at El-Emam El-Hussien Village, El-Bostan area, El-Delengate, Behaira Governorate, Egypt, as pots experiment. The experimental units were 72 as a plastic pots, including 3 levels of salinity irrigation water $\times 2$ irrigation water types (magnetic and non-magnetic) $\times 2$ soil types (clay and sandy soil) $\times 2$ biofertilizers $\times 3$ replicates. Plastic pots of $25 \mathrm{~cm}$ depth and $35 \mathrm{~cm}$ diameter were used in this study. The layout of the experiment was a split-split-plot design of each soil, with the main plots arranged in a randomized complete blocks design. These pots were divided into two main groups (36 pot/main group) representing the used two soils, i. e. clay and sandy soil, respectively. Each pot of the first main groups was filled with $10 \mathrm{~kg}$ of clay 
soil. On the other hand, each pot of the second main group was filled by $10 \mathrm{~kg}$ of sandy soil. The pots of each main group were divided into two sub groups (18 pot/sub group) representing the treatments of biofertilization (without and with biofertilizer). Before planting, all pots were fertilized by ordinary super phosphate $\left(15.5 \% \mathrm{P}_{2} \mathrm{O}_{5}\right)$ at rate of 200 $\mathrm{kg} / \mathrm{fed}$. $(2 \mathrm{~g} / \mathrm{pot})+100 \mathrm{~kg} / \mathrm{fed}$. $(1 \mathrm{~g} / \mathrm{pot})$ of agricultural sulphur $+30 \mathrm{~m}^{3} /$ fed. $(0.3$ $\mathrm{cm}^{3} /$ pot) of compost, and good mixed. Also, all pots were received potassium fertilizer in the form of potassium sulphate $\left(48 \% \mathrm{~K}_{2} \mathrm{O}\right)$ at rate of $100 \mathrm{~kg} \mathrm{l}$ fed. (1 g/pot) and ammonium nitrate (33 $\% \mathrm{~N}$ ) at rate of $250 \mathrm{~kg} / \mathrm{fed}$. ( $2.5 \mathrm{~g} / \mathrm{pot})$, in two equal doses after 15 and 30 days of planting, in both two soil types. Directly before planting, the pots of the second sub groups of both clay and sandy soil were fertilized by the used biofertilizer (Rhizobim phaseolease) as a coating seeds. Common beans seeds (Phaseolus vulgaris L.), Nebrsca cv. were sown at $15^{\text {th }}$ of October 2015 by four seeds in each pot. Then the pots of the two sub groups of each soil were divided into three sub sub groups (6 pot/sub sub group) representing salinity levels of used irrigation water resources (IW1, IW2 and IW3). Finally, the six pots of each sub sub groups were divided into two groups (3 pot I group) representing magnetization treatment (non-magnetized and magnetized irrigation water). Moisture content of the potted soils was kept constantly at $60 \%$ of the water holding capacity (WHC) of each soil. All pots were irrigated every three days. After 10 days of sowing, seedlings of each pot were thinned to two plants. After $\mathbf{4 5}$ days of planting, plants of each pot were harvested as whole. Directly the plant samples of each pot was washed several times with tap water to remove the soil particles attached to the plant roots and again washed with distilled water, then the whole plants were separated into roots and shoots. Each organs were weighed to obtain the fresh weight. Nodules formed on the fresh roots were counted. The plant materials were oven-dried at $70^{\circ} \mathrm{C}$ for 48 hours to record the dry weight of roots and shoots, and the obtained data were statistically analyzed according to Gomez and Gomez, (1984).

\section{RESULTS AND DISCUSSION \\ i. Effect of the studied treatments on nodulation efficiency. a-Irrigation water salinity Level}

The presented data in Table (3) show that, in the two investigated soils, roots number formed on the roots of common bean significantly decreased with the increase salinity levels from $300 \mathrm{mg} \mathrm{l}^{-1}$ (IW1) to $1900 \mathrm{mg} \mathrm{l}^{-1}$ (IW3) at the same treatment of biofertilization with either of un-magnetized or magnetized water. For example, this number was decreased from 42 to 27 with a relative change value (RC) of $-35 \%$ and from 12 to 3 with (RC) value of $-72 \%$ in the common bean plants grown in clay and sandy soil irrigated by un-magnetized IW1 and IW3 without bio fertilization, respectively. These findings means that, increase salinity levels of irrigation water have a high decrease effect on the nodules number formed on the roots of common bean plants grown in sandy soil compared to that found with the plants grown in clay soil at the same treatment as shown from the calculated values of RC (Table 3). The decrease effects of irrigation water salinity on nodules number formed on the roots of common bean plants attributed mainly to the harmful effect of irrigation water salinity on root growth (Length and fresh and dry yields) as mentioned before that by Nada and Tantawy (2012) and Tantawy et al. (2015). 
Manal F.A. Tantawy, et al.,

Table (3): Number of root nedules plant of common bean treated by biofertilizer and its relation changes "Rcs" \% affected by salinity level of unmagnetized and magnetized water at $\mathbf{4 5}$ old days.

\begin{tabular}{|c|c|c|c|c|c|c|c|c|c|c|}
\hline \multicolumn{3}{|c|}{ Irrigation Water } & \multicolumn{4}{|c|}{ Clay soil } & \multicolumn{4}{|c|}{ Sandy soil } \\
\hline \multirow{2}{*}{$\stackrel{\Perp}{\stackrel{2}{\gtrless}}$} & \multirow{2}{*}{ Source } & \multirow{2}{*}{$\begin{array}{l}\text { Salinity } \\
\text { (mg/L) }\end{array}$} & \multicolumn{2}{|c|}{$\begin{array}{c}\text { Without } \\
\text { biofertilizer }\end{array}$} & \multicolumn{2}{|c|}{$\begin{array}{c}\text { With } \\
\text { biofertilizer }\end{array}$} & \multicolumn{2}{|c|}{$\begin{array}{c}\text { Without } \\
\text { biofertilizer }\end{array}$} & \multicolumn{2}{|c|}{$\begin{array}{c}\text { With } \\
\text { Biofertilizer }\end{array}$} \\
\hline & & & No & RCS\% & No & RCS\% & No & RCS\% & No & RCS\% \\
\hline \multirow{4}{*}{ 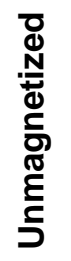 } & IW1 & 300 & 42 & -26 & 84 & -34 & 12 & -33 & 17 & -17 \\
\hline & IW2 & 700 & 31 & -35 & 55 & -57 & 8 & -75 & 14 & -70 \\
\hline & IW3 & 1900 & 27 & & 36 & & 3 & & 5 & \\
\hline & & Mean & 33 & & 58 & & 7 & & 12 & \\
\hline \multirow{4}{*}{ 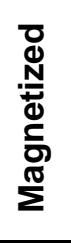 } & IW1 & 300 & 101 & -20 & 128 & -27 & 32 & -50 & 45 & -33 \\
\hline & IW2 & 700 & 80 & -26 & 93 & -36 & 16 & -71 & 30 & -73 \\
\hline & IW3 & 1900 & 74 & & 81 & & 9 & & 12 & \\
\hline & & Mean & 85 & & 100 & & 19 & & 29 & \\
\hline \multicolumn{6}{|c|}{ LSD at 0.05} & \multicolumn{5}{|c|}{ Number of root } \\
\hline \multicolumn{6}{|c|}{ A L.S,D value for Soil treatments } & \multicolumn{5}{|c|}{1.907946} \\
\hline \multicolumn{6}{|c|}{ B L.S.D.value for Fertilizer tratments } & \multicolumn{5}{|c|}{1.557832} \\
\hline \multicolumn{6}{|c|}{ C L.S.D.valuefor Magnetic tratments } & \multicolumn{5}{|c|}{1.557832} \\
\hline \multicolumn{6}{|c|}{ D L.S.D.value for Salinity tratments } & \multicolumn{5}{|c|}{1.557832} \\
\hline \multicolumn{6}{|c|}{ ABCD L.S.D value for Interaction between treatments } & \multicolumn{5}{|c|}{5.396487} \\
\hline
\end{tabular}

Generally, at the same salinity level of irrigation water with the treatments of bio fertilizer and magnetic application, nodules number formed on the roots of common beans plants grown on clay soil were higher than those formed on the roots under sandy soil conditions (Table 3). These findings resulted from several reasons such as high clay soil content of available macro- and micro nutrients and biomass as well as the high biological activities compared with these in sandy soil (El-Noamany, 2013). The high negative RC values of nodules number formed on the roots of common bean plants in sandy soil irrigated by "IW2" and "IW3" compared with these found under clay soil conditions may be resulted from the high solubility of added salts which increased its harmful effect on both plant growth and biological activity.

\section{b- Magnetized technique application}

The presented data in Tables (3 and 4) show the root nodules formed on the roots of common bean plants grown on clay and sandy soils and its relative changes "RCM"\% affected by applying magnetic technique. These data show that, with the same salinity level of irrigation water. i.e 300 "IW1", 700 "IW2" and $1900 \mathrm{mg} \mathrm{l-1} \mathrm{"IW3"} \mathrm{applying} \mathrm{magnetic}$ technique resulted in a significant increase in the number of the nodules formed on the roots of common bean plants in clay and sand soil and also with different treatments of bio fertilization. These increases may be cleared from "RCM" values presented in Table (4), 
where these values were positive. The positive effect of magnetic technique application with irrigation water resulted from the magnetic fields on physical and chemical properties of irrigation water as well as its effect on soil. physical, chemical and biological properties and its available content of essential nutrients and their reflections on plant growth (Aghamir et al., 2016 and ElNahas, 2017). Hilal and Hillal (2000) reported thatmagnetized water have three main effects. i.e.1-Increasing the leeching of excess soluble salts, 2- Lowing soil alkalinity and 3- Dissolving slightly soluble salts such as carbonates, phosphates and sulphates, adding to that the increase in soil nutrients availability. Also, Hassan (2015) found that, soil desalination was enhanced up to $25 \%$ and the soil available nutrients content in the Rhizosphere were increased by 33-50 $\%$ when irrigation with magnetized water. With all salinity levels of irrigation water, "RCM" values of nodules number formed on the roots of common bean plants grown in clay soil were higher positively than those found with the found under sandy soil conditions (Table 4). These findings were found with different treatments of bio fertilizer. Also, these results may be concluded that, using magnetized water in irrigation of clay soil have a high positive effect on the decrease of salt stress compared with that observed with sandy soil.

\section{c- Biofertilizer}

Data in Tables (3 and 5) show number of nodules formed on the roots of common bean plants under clay and sandy soils conditions in relations with the treatments of bio fertilizer (Rhizobium leguminosarum biovar phaseoli) and its relative changes "RCB" (\%) at different salinity levels of irrigation water either of un-magnetized or magnetized. These data show a significant increase in the nodules number formed on the roots of common bean plants grown in clay and sandy soil due to bio fertilizer application compared with those found on the roots of the plants un received bio fertilization .For example with the un-magnetized "IW2"nodules were increased from 31 to 55 with RCB value of $77.4 \%$ and from 8 to 14 with RCM value of $75 \%$ due to bio fertilizer application under clay and sandy soil condition, respectively. All RCB values of nodules number were positive and decreased with the increase salinity level of irrigation water. The found increases of nodules number formed on the roots of common bean plants attributed to the enhanced effects of bio fertilization on plant growth, biological biomass and enzymes activities (Abd El-Wahab et al., 2009 and Ahmed et al., 2013).

Table (4): Relative change "RCM"of root nodules number affected by magnetized water at different salinity levels of common bean plants treated by bio fertilizer at 45 old day.

\begin{tabular}{|l|c|c|c|c|c|}
\hline \multicolumn{2}{|l|}{ Irrigation water } & \multicolumn{2}{|c|}{ Clayey soil } & \multicolumn{2}{c|}{ Sandy soil } \\
\hline Source & $\begin{array}{c}\text { Salinity } \\
\text { (mg/L) }\end{array}$ & $\begin{array}{c}\text { Without } \\
\text { biofertilizer }\end{array}$ & $\begin{array}{c}\text { With } \\
\text { biofertilizer }\end{array}$ & $\begin{array}{c}\text { Without } \\
\text { biofertilizer }\end{array}$ & $\begin{array}{c}\text { With } \\
\text { biofertilizer }\end{array}$ \\
\hline & & & & & \\
IW1 & 300 & 140.47 & 52.38 & 166.66 & 164 \\
IW2 & 700 & 158.1 & 69.1 & 100 & 114.28 \\
IW3 & 1900 & 174.1 & 125 & 200 & 140 \\
\hline
\end{tabular}


Manal F.A. Tantawy, et al.,

Table (5): Relative changes "RCB"\% of root nedules number affected by biofertilization of common bean plants irrigated by unmagnetized and magnetized water varied in their salinity at $\mathbf{4 5}$ old day.

\begin{tabular}{|l|c|c|c|c|c|}
\hline \multicolumn{2}{|l|}{ Irrigation water } & \multicolumn{2}{|c|}{ Clayey soil } & \multicolumn{2}{c|}{ Sandy soil } \\
\hline Source & $\begin{array}{c}\text { Salinity } \\
\text { (mg/L) }\end{array}$ & $\begin{array}{c}\text { Unmagnetized } \\
\text { water }\end{array}$ & $\begin{array}{c}\text { Magnetized } \\
\text { water }\end{array}$ & $\begin{array}{c}\text { Unmagnetized } \\
\text { water }\end{array}$ & $\begin{array}{c}\text { Magnetized } \\
\text { water }\end{array}$ \\
\hline IW1 & 300 & 100 & 26.7 & 41.66 & 40.62 \\
IW2 & 700 & 77.4 & 16.25 & 75 & 87.5 \\
IW3 & 1900 & 33.3 & 9.5 & 66.66 & 33.33 \\
\hline
\end{tabular}

In addition, data in Table (3) show a wide variations in the nodules number formed on the roots of common bean plants grown in clay soil and that formed under sandy soil conditions due to the same treatment of bio fertilization. This variation reveals to the high efficiency of bio fertilizer in clay soil compared to that in sandy soil which may be resulted from the high clay soil content of biomass and available essential plant nutrients. In this respect, El-Noamany (2013) found that nodules number formed on the roots of Faba bean grown in clay soil due to bio fertilization was higher that formed in the roots of the plants grown in sandy calcareous soil.

\section{d-Combined effect of salinity level, magnetic technique and bio fertilizer \\ Blues the effect of individual} treatments of salinity levels of irrigation water, magnetic technique and bio fertilization on the number nodules formed on the roots of common bean plants grown in clay and sandy soils, data in Table (3) show also the effect of double and treble interaction of the studied treatments. These data show that, applying magnetic technique in combination without or with biofertilizer addition to common bean plants in both clay and sandy soil resulted in a significant increases of nodules number formed in the roots of common bean plants under different salinity levels of irrigation water. These findings means that, the harmful and decrease in nodules formed due to increase in the salinity level of irrigation water may be decreased by applying magnetic technique and bio fertilization application individually and in together.

Therefore, overcome on the salt stress and to enhanced nodulation on the roots of pea plants may be occurred by applying magnetic technique and bio fertilization additives.

\section{ii. Effect of The Studied} Treatments on Fresh and Dry Matter Yields of Common bean Plants (shoots) after 45 Old Day

\section{a-Irrigation water salinity level}

Fresh and dry matter yield $\left(\mathrm{g} \mathrm{pot}^{-1}\right)$ of common bean plants (shoots) and its relative change RCS (\%) at 45 old day affected by salinity level of irrigation water as listed in Table (6) show that, increasing salinity level of irrigation water from 300 to 700 and from 700 to $1900 \mathrm{mg} \mathrm{I}^{-1}$ resulted in a significant decrease in both fresh and dry matter yields of common bean plants shoots. These decreases were found with the plants grown in both clay and sandy soils. Also, the decrease effect of salinity levels of irrigation water on fresh and dry matter yields of shoots was observed with all magnetic and bio fertilization treatments. Thus, all RCS values were negative. For example, fresh weight of 
shoots was decreased from 27.86 to $24.29 \mathrm{~g} \mathrm{pot}^{-1}$ with RCS value $-12.81 \%$ in clay soil and from 28.31 to $17.73 \mathrm{~g} \mathrm{pot}^{-1}$ with RCS value of $-37.37 \%$ in sandy soil with the increase salinity level of irrigation water from 300 to $700 \mathrm{mg} \mathrm{l}^{-1}$ without applying magnetic technique and also without bio fertilization, respectively. This example reveals that, both fresh and dry matter yields of common bean plants (shoots) grown in clay soil were higher than those found with the plants grown in sandy soil at the same salinity level of irrigation water, while at the same treatment RCS of fresh and dry matter yields under clay soil conditions were more negative compared with those found with the plants grown in sandy soil. Before that, the decrease effect of irrigation water salinity on plant growth and dry matter yields was pre-mentioned by Nada and Tantawy (2012).

Table (6): Fresh and dry matter yield (g/pet) of common bean (shoots) plants treated by bio fertilizer and their relative changes "RCS"\% affected by salinity level of unmagnified and magnetized irrigation water after $\mathbf{4 5}$ old day.

\begin{tabular}{|c|c|c|c|c|c|c|c|c|c|c|c|}
\hline \multirow{2}{*}{\begin{tabular}{|l|} 
Soil \\
Type
\end{tabular}} & \multicolumn{3}{|c|}{ Irrigation water } & \multicolumn{4}{|c|}{ Fresh weight (g/pet) } & \multicolumn{4}{|c|}{ Dry matter (g/pet) } \\
\hline & $\begin{array}{l}\text { Type } \\
\text { (a) }\end{array}$ & Source & $\begin{array}{c}\text { Salinity } \\
\text { (mg/L) }\end{array}$ & \multicolumn{2}{|c|}{$\begin{array}{c}\text { Without } \\
\text { biofertilizer } \odot\end{array}$} & \multicolumn{2}{|c|}{$\begin{array}{c}\text { With } \\
\text { biofertilizer }\end{array}$} & \multicolumn{2}{|c|}{$\begin{array}{c}\text { Without } \\
\text { biofertilizer }\end{array}$} & \multicolumn{2}{|c|}{$\begin{array}{c}\text { With } \\
\text { biofertilizer }\end{array}$} \\
\hline \multirow{7}{*}{ 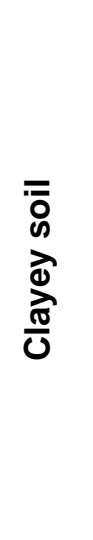 } & \multirow{3}{*}{ 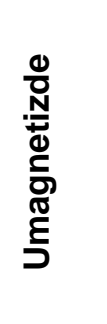 } & \multirow{3}{*}{$\begin{array}{l}\text { IW1 } \\
\text { IW2 } \\
\text { IW3 }\end{array}$} & & $g / \operatorname{pet}(b)$ & RCS\% & \multirow{2}{*}{\begin{tabular}{|l|} 
g/pet \\
42.27 \\
33.17 \\
31.47
\end{tabular}} & \multirow{2}{*}{\begin{tabular}{|l|} 
RCS\% \\
$21.53-$ \\
$25.55-$
\end{tabular}} & \multirow{2}{*}{\begin{tabular}{|c|} 
g/pet \\
4.82 \\
2.70 \\
1.55 \\
\end{tabular}} & \multirow{2}{*}{\begin{tabular}{|l|} 
RCS $\%$ \\
$43.98-$ \\
$67.84-$
\end{tabular}} & \multirow{2}{*}{\begin{tabular}{|c|} 
g/pet \\
6.38 \\
4.57 \\
3.89 \\
\end{tabular}} & \multirow{3}{*}{\begin{tabular}{|l} 
RCS $\%$ \\
28.37 \\
39.03
\end{tabular}} \\
\hline & & & $\begin{array}{c}300 \\
700 \\
1900\end{array}$ & $\begin{array}{l}27.86 \\
24.29 \\
15.05\end{array}$ & $\begin{array}{l}12.81- \\
45.98-\end{array}$ & & & & & & \\
\hline & & & Mean & 22.4 & & 35.64 & & 3.02 & & 4.95 & \\
\hline & \multirow{4}{*}{ 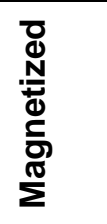 } & \multirow{4}{*}{$\begin{array}{l}\text { IW1 } \\
\text { IW2 } \\
\text { IW3 }\end{array}$} & 300 & \multirow{3}{*}{$\begin{array}{l}30.88 \\
29.54 \\
21.08\end{array}$} & & \multirow{3}{*}{$\begin{array}{l}54.66 \\
38.67 \\
35.32\end{array}$} & & 7.24 & & 8.22 & \multirow{4}{*}{$\begin{array}{l}-23.23 \\
44.89\end{array}$} \\
\hline & & & 700 & & 4.34- & & $29.25-$ & 5.35 & 26.1- & 6.31 & \\
\hline & & & 1900 & & 31.74- & & 35.38 & 3.59 & 50.41- & 4.53 & \\
\hline & & & $\mathrm{Me}$ & \multirow{4}{*}{$\begin{array}{l}27.17 \\
28.31 \\
17.73 \\
13.33\end{array}$} & & 42.8 & & 5.3 & & 6.35 & \\
\hline \multirow{8}{*}{ 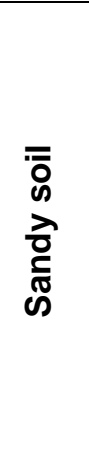 } & \multirow{4}{*}{ 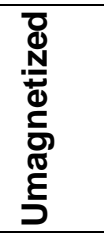 } & \multirow{4}{*}{$\begin{array}{l}\text { IW1 } \\
\text { IW2 } \\
\text { IW3 }\end{array}$} & 300 & & & 41.21 & & 4.57 & & 5.32 & \\
\hline & & & 700 & & 37.37- & 32.62 & 20.84- & 3.81 & $16.63-$ & 4.36 & -18 \\
\hline & & & 1900 & & -52.91 & 29.29 & 28.93- & 2.44 & 46.61- & 3.4 & -36.8 \\
\hline & & & Mean & 19.79 & & 34.37 & & 3.61 & & 4.36 & \\
\hline & D & IW1 & 30 & 37.07 & & 52.26 & & 5.23 & & 8.18 & \\
\hline & $\stackrel{N}{=}$ & IW2 & 700 & 34.59 & $6.69-$ & 37.48 & 28.28- & 4.46 & $14.72-$ & 6.04 & -26.1 \\
\hline & $=$ & IW3 & 1900 & 25.68 & 30.73- & 36.16 & 30.81- & 3.61 & 30.98- & 4.13 & -49.51 \\
\hline & & & Mean & 32.45 & & 41.97 & & 4.43 & & 6.11 & \\
\hline & & at 0.0 & & & .S.D. at 0 . & & Fres & eight & & Dry weic & \\
\hline A L & S,D valu & e for Soil & treatme & & A & & 0.2803 & & & 0.09610 & \\
\hline B L.S & .value & for Fertili & izer tratm & ents & B & & 0.2288 & & & 0.0784 & \\
\hline C L.S & D.value & for Magne & etic tratm & ients & C & & 0.2288 & & & 0.0784 & \\
\hline D L. & D.value & for Salin & ity tratm & ents & D & & 0.2288 & & & 0.0784 & \\
\hline & $\begin{array}{l}\text { L.S.D } \\
\text { betwe }\end{array}$ & $\begin{array}{l}\text { value for } \\
\text { en treatm }\end{array}$ & $\begin{array}{l}\text { Interact } \\
\text { nents }\end{array}$ & & Abcd & & 0.7928 & & & 0.27182 & \\
\hline
\end{tabular}


Manal F.A. Tantawy, et al.,

Recently, El-Nahas (2017) pointed out that, increasing salinity levels of unmagnetized and magnetized irrigation water resulted in a significant decrease of grains wheat germination and also, the dry weight of wheat roots and shoots.

\section{b-Magnetic technique}

Data of common bean plants (shoots) fresh and dry matter yields $\left(\mathrm{g} \mathrm{pot}^{-1}\right)$ and their relative changes RCM (\%) affected by applying magnetic technique as listed in Tables (5 and 7) show that, both fresh and dry weights were increased significantly in the plants irrigated by magnetized water compared with these found with the plants irrigated with unmagnetized water at the same salinity level and bio fertilization treatment.

So, all RCM in Table (7) were positive. These findings were similarity in clay and sandy soils at $\mathbf{4 5}$ day of plant age. For example, with magnetized "IW3" in clay soil RCM values were 40.07 and $\mathbf{1 2 . 2 3} \%$ for fresh weights and were 131.61 and $16.45 \%$ for dry weights in the shoots.of common bean plants unfertilized and fertilized by bio additives, respectively. This example show that, RCM for both shoots fresh and dry matter yields of common bean plants un received bio fertilization were higher than those found with the plants received bio fertilizer under clay soil conditions. No clear trend for thus effect was observed with the plants grown in sandy soil. In general, RCM of shoots fresh and dry matter yields at the same salinity level of irrigation water and bio fertilizer treatment for common bean plants grown in clay soil were higher than those found with the plants grown in sandy soil. These findings means that, applying magnetic technique on saline water have a superior increase effect on plant growth as well as decrease salt stress under clay soil compared with those found in sandy soil. In this respect, Omran (2017) pointed out a significant increase in both fresh and dry matter yield of wheat and barley (shoots) as a result of irrigation using magnetized tap and saline water compared with that found with un-magnetized one.

Table (7): Effect of magnetized water on the relative change "RCM" of fresh and dry matter yields of common bean plants (shoots) treated by bio fertilizer under different levels of irrigation water at $\mathbf{4 5}$ old day

\begin{tabular}{|c|c|c|c|c|c|c|}
\hline \multirow{2}{*}{$\begin{array}{l}\text { Soil } \\
\text { type }\end{array}$} & \multicolumn{2}{|c|}{ Irrigation water } & \multicolumn{2}{|c|}{ Fresh weight } & \multicolumn{2}{|c|}{ Dry ewight } \\
\hline & Source & Salinity & $\begin{array}{c}\text { Without } \\
\text { biofertilizer }\end{array}$ & $\begin{array}{c}\text { With } \\
\text { biofertilizer }\end{array}$ & $\begin{array}{c}\text { Without } \\
\text { biofertilizer }\end{array}$ & $\begin{array}{c}\text { With } \\
\text { biofertilizer }\end{array}$ \\
\hline \multirow{4}{*}{$\begin{array}{l}\overline{\overline{0}} \\
0 \\
\text { बे } \\
\text { ते } \\
\frac{\sigma}{U}\end{array}$} & Iw1 & 300 & 10.84 & 29.31 & 50.21 & 28.84 \\
\hline & Iw2 & 700 & 21.61 & 16.58 & 98.15 & 38.07 \\
\hline & Iw3 & 1900 & 40.07 & 12.23 & 131.61 & 16.45 \\
\hline & & Mean & 24.17 & 19.37 & 93.32 & 27.78 \\
\hline \multirow{4}{*}{ 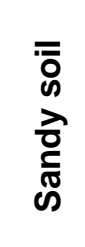 } & \multirow{4}{*}{$\begin{array}{l}\text { Iw1 } \\
\text { Iw2 } \\
\text { Iw3 }\end{array}$} & 300 & 30.94 & 26.81 & 14.44 & 53.76 \\
\hline & & 700 & 95.09 & 14.90 & 17.06 & 38.53 \\
\hline & & 1900 & 92.65 & 23.46 & 47.95 & 21.47 \\
\hline & & Mean & 72.89 & 21.72 & 26.48 & 37.92 \\
\hline
\end{tabular}




\section{c- Biofertilization}

Data in Tables (6 and 8) show the effect of bio fertilizer application (Rhizobium leguminosarum biovar phaseoli) or fresh and dry weights (g pot $^{-1}$ ) of pea plants (shoots) after 45 days of planting under clay and sandy soil conditions as well as its relative changes RCB (\%). With different treatments of un - and magnetized saline irrigation water, bio fertilizer application resulted in a significant increase of fresh and dry weights of common bean plants (shoots). Thus, all RCB (\%) values for both fresh and dry weights affected by biofertilizer applications were positive compared with the treatments un received bio fertilizer. For example, RCB of shoots of common bean plants grown in clay soil irrigated by un-magnetized irrigation water at level of $1900 \mathrm{mg} \mathrm{l}^{-1}$ (IW3) were 109.1 and 150.97 $\%$ and were 119.73 and $39.34 \%$ with the plants grown in sandy soil for fresh and dry weights, respectively. This example show that, bio fertilizer application have a greater increase effect on fresh weight compared with that found in the dry weight in clay and sandy soils. In this respect, El-Noamany (2013) and Faiyed (2014) found similar results with faba bean plants treated by bio fertilizer in clay and calcareous sandy soils. Recently, Abdel Aal et al., (2018) and ElTahlawy (2018) obtained on similar $r$ increases of bio fertilizers on grass wheat plants growth and their dry matter yields under sandy soil conditions.

d-Combined effect of salinity level, magnetic technique and bio fertilizer.

The presented data in Tables $(6,7$ and 8) show the combined effects of the studied three factors on fresh and dry matter yields $\left(\mathrm{g} \mathrm{pot}^{-1}\right)$ of common bean plants (shoots) at $\mathbf{4 5}$ day after planting. These data showed that, the treatments of magnetic technique and bio fertilization individually and in together resulted in a significant increases of fresh and dry weights of pea plants (shoots) planted in clay and sandy soils under different salinity levels of irrigation water $\left(300,700\right.$ and $\left.1900 \mathrm{mg} \mathrm{l}^{-1}\right)$, where the highest increases were resulted from the combined treatments. These results means that, applying magnetic technique with saline water and bio fertilizer application reduced the harmful effect of salinity stress on plant growth especially with their combined applications .

Table (8): Effect of bio fertilizer on relative changes "RCB"\% of fresh and dry matter yields of common bean (shoots) plants irrigated by magnetized and magnetized water at different salinity levels at $\mathbf{4 5}$ old day.

\begin{tabular}{|c|c|c|c|c|c|c|}
\hline \multicolumn{3}{|c|}{ Irrigation water } & \multicolumn{2}{|c|}{ Clayey soil } & \multicolumn{2}{|c|}{ Sandy soil } \\
\hline Type & Source & Salinity & $\begin{array}{c}\text { Fresh } \\
\text { weight }\end{array}$ & $\begin{array}{c}\text { Dry } \\
\text { weight }\end{array}$ & $\begin{array}{c}\text { Fresh } \\
\text { weight }\end{array}$ & Dry weight \\
\hline \multirow{4}{*}{ 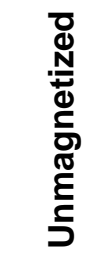 } & IW1 & 300 & 51.72 & 32.36 & 45.57 & 16.41 \\
\hline & IW2 & 700 & 36.56 & 69.25 & 83.98 & 14.44 \\
\hline & IW3 & 1900 & 109.1 & 150.97 & 119.73 & 39.34 \\
\hline & & Mean & 65.79 & 84.19 & 83.09 & 23.39 \\
\hline \multirow{4}{*}{ 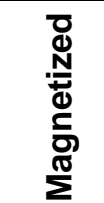 } & \multirow{4}{*}{$\begin{array}{l}\text { IW1 } \\
\text { IW2 } \\
\text { IW3 }\end{array}$} & 300 & 77.01 & 13.54 & 40.98 & 56.41 \\
\hline & & 700 & 30.91 & 17.94 & 8.36 & 35.43 \\
\hline & & 1900 & 67.55 & 26.18 & 40.81 & 14.40 \\
\hline & & Mean & 58.49 & 19.22 & 30.05 & 35.41 \\
\hline
\end{tabular}




\section{REFRENCES}

Abdel Aal, M. H., D. M. Khalifa and I. M. Abdalla (2018). Impacts of different rates of compost, proline-spray and irrigation on some soil properties and sudan grass grown in saline soil. Menoufia J. Soil Sci., 3 (December): 267- 281.

Abdel-Wahab, A. F. M., A. M. M. Biomy and W. M. El-Farghal (2009). Cocomposting of plant residues and their utility with micronutrients to enhance productivity of faba beanRhizobium symbiosis under sandy soil conditions. Egypt. J. Appl. Sci., 24: 343-368.

Aghamir, F., H. Bahrami and M. Jafar (2016). Seed germination and seedling growth of bean (Phaseolus vulgaris) as influenced by magnetized saline water. Eurasian J. Soil Sci., 5 (1): 1-8.

Ahmed, I., M. Akhtar, H. Asghar and M. Khalid (2013). Influence of Rhizobium applied in combination with micronutrients on man bean. Pakistan J. Life Soc. Sci., 11(1): 53-59.

Cottenie, A., M. Verloo, L. Kiekens, G. Velghe and R. Camerlynck (1982). "Chemical Analysis of Plants and Soils". Lab. Analytical and Agrochem, State Univ., Ghent-Belgium.

Deng, B. and X. Pang (2007). Variations of optic properties of water under action of static magnetic field. Chinese Science Bulletin, 52 (23): 3179-3182.

El-Nahas, H. A. A. H. (2017). Improving irrigation water efficiency for desert soils. M. Sc. Thesis Fac. of Agric., AlAzhar Univ., Egypt.

El-Noamany, N. E. A. (2013). Studies on diazotrophy in soils under different conditions. M. Sc. Thesis Fac. of Agric., Minufiya Univ., Egypt.

El-Tahlawy, Y. A (2018). Effect of microbial additives and compost tea on growth and productivity of wheat plants fertilized by mineral nitrogen in sandy soil. Menoufia J. Soil Sci., 3 (December): 301- 316.

Faiyad, R. M. N. (2014). Bioremediation of chemically polluted soils and its effect on plant growth. Ph. D. Thesis Fac. of Agric., Minufiya Univ., Egypt.

Garcia-Reina, F. and L. A. Pascual (2001). Influence of a stationary magnetic field on water relations in lettuce seeds. Part I: Theoretical considerations. Bioelectromagnetics, 22 (8): 58-595.

Gomez, K. A. and A. A. Gomez (1984). "Statistical Procedures for Agricultural". Research, $2^{\text {nd }}$ (Ed.) John Wily and Sons, New York.

Hassan, K. K. (2015). Magnetic treatment of brackish water for sustainable agriculture. M. Sc. Thesis School of Sciences and Engineering, the American University in Cairo, Egypt.

Hilal, M. H. and M. M. Hillal (2000). Application of magnetic technologies in desert agriculture. II-Effect of magnetic treatments of irrigation water on water on salt distribution in olive and citrus field and induced changes of ionic balance in soil and plant. Egypt. J. Soil Sci., 40(3): 423435.

Klute, A. (1986). "Methods of Soil Analysis". American Society of Agron., Inc. Soil Soc. of Amer., Inc Madison Wisconsin, USA, $2^{\text {nd }}$ Edition.

Munns, R. (2002). Comparative physiology of salt and water stress. Plant Cell Environ. 25: 239-250.

Muraleedharan, H., S. Seshadri and K. Perumal (2010). Biofertilizer (Phosphobacteria). Shri AMM Murugappa Chettiar Research Centre, Taramani, Chennai $600 \quad 113$. December, 2010.

Nada, W. M. and M. F. Tantawy (2012). Effect of humic acid application on soil properties and plant tolerance for high salinity levels of irrigation water. Egypt. J. Soil Sci., 52 (4): 507-525. 
Omami, E. N. (2005). Response of amaranth of salinity stress. Ph. D. Thesis Fac. of Agric., Univ. Pretoria, p. 119.

Omran, W. M. (2017). Impact of magnetization and salinity of irrigation water on some soil properties and growth of wheat and barley. Menoufia J. Soil Sci., 2 (October): 247- 260.

Page, A. L., R. H. Miller and D. R. Keeney (1982). "Methods of Soil Analysis". Part 2 : Chemical and Microbiological Properties (2 ${ }^{\text {nd }}$ ed. ) Amer. Soc. Agron. In Soil Sci. Soc. Amer. Inc. Madison, Wisconsin, U.S.A.

Pang, X. F. and B. Deng (2008). Investigation of changes in properties of water under the action of a magnetic field. Sci. China Ser G-Phys Mech. Astron, 51 (11): 1621-1632.

Parida, A. K. and A. B. Das (2005). Salt tolerance and salinity effect on plants: A review. Ecotoxicology and Environmental Safety, 60 (3): 324-349.

Takatshinko, Y. (1997). Hydro magnetic systems and their role in creating micro climate. International Symposium on Sustainable Management of Salt Affected Soils, Cairo, Egypt, 22 - 28 Sept.

Tantawy, M. F., R. A. Khalil, E. A. AbouHussien and A. M. Soliman (2015). Interaction between humic acids and neutral salts on plant growth. Minufiya J. Agric. Res., 40 (1): 195-212.

Zhu, J. K. (2001). Plant salt tolerance. Trends Plant Sci., 6: 66-71. 
التاثير المشترك للماء المالح والممغنط والتسميد الحيوي علي التعقد ونمو نباتات الفاصوليا النامية في الاراضي الطينية والرملية

منال فتحي عبد السلام طنطاوي(')، محمد نجيب السيد فياض(()، فاطمة سعد الثافعي()،

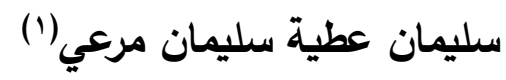

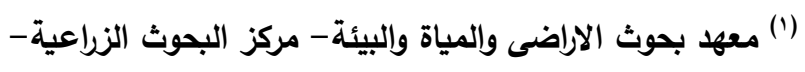
(") الملخص العربي

اجريت تجربة اصص خلا شتاء 10 ـ ب في مزرعة خاصة علي ارض طينية ورملية ذات خواص طبيعية وكيميائية

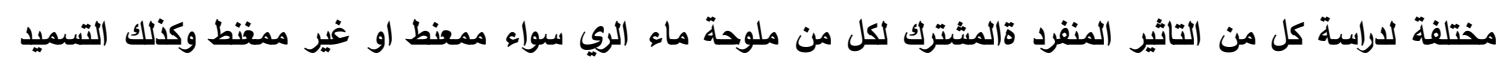

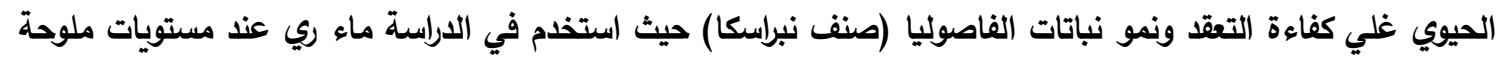

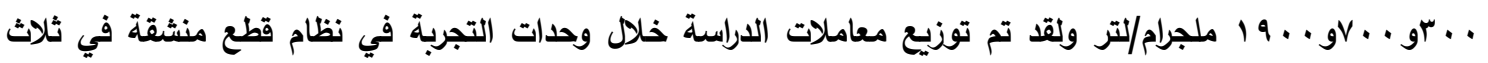

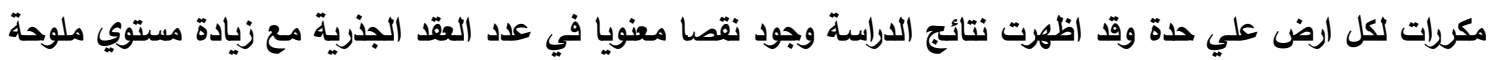

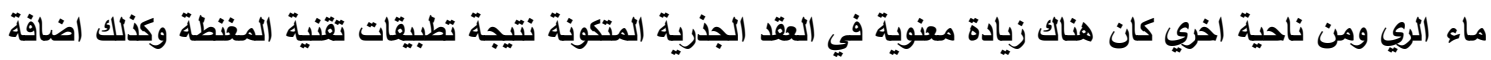

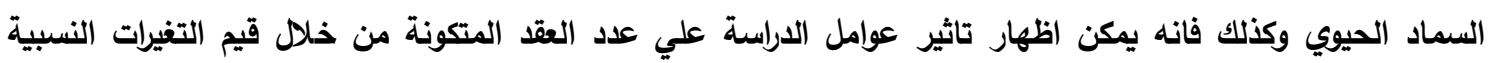

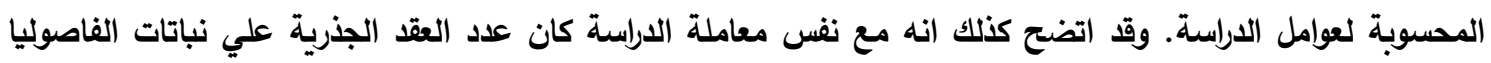

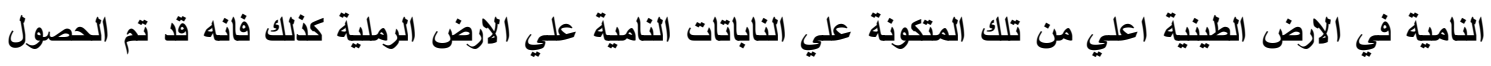

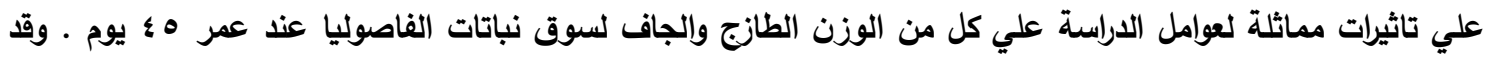

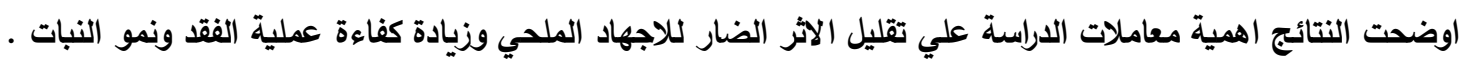

